\title{
Establishing a Core List of Journals for Forestry: A Citation Analysis from Faculty at Southern Universities
}

\author{
Paul Kelsey and Tom Diamond
}

\begin{abstract}
Citations of articles published from 1990 to 2002 of faculty teaching at selected southern universities are counted and analyzed to form a core list of the most highly cited journals for the field of forestry. Core lists are developed for assistant, associate, and full professors; and citation differences among the three groups are analyzed. The core list of journals is compared with the list of primary forestry serials compiled by the Cornell Core Agricultural Literature Project. The analysis focuses on the similarities and differences of both studies, and discusses the importance of ecological and interdisciplinary journals to forestry research.
\end{abstract}

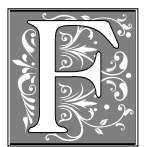

orest science has become increasingly broad over the years and now covers a vast array of subject specializations. ${ }^{1}$ The Society of American Foresters recently defined the word forest as "an ecosystem characterized by ... tree cover" reflecting a "modern 'ecosystem' approach" to forest science that is more inclusive in nature than past definitions. ${ }^{2}$ Scientists conduct research in forest ecology and soils, forest entomology, forest genetics, biometrics, urban forestry, and medicinal plant physiology, to list only a few of the diverse subject areas in the field. Thomas W. Steele and Jeffrey C. Stier analyzed citations appearing in the journal Forest Science and concluded that interdisciplinary research contributed a "measurable and positive impact" on forestry literature. ${ }^{3}$ Forestry schools are adapting to meet the changing expectations of forestry employers seeking a "broader and more integrative" practice of forestry. For example, in 2002, the School of Forestry, Wildlife, and Fisheries at Louisiana State University (LSU) changed its name to the School of Renewable Natural Resources to reflect a "more holistic" mission dedicated to interdisciplinary and ecological research. ${ }^{5}$

The forestry literature reflects these changing trends. Although forest scientists still use journals specific to forestry, such as Forest Science and Forest Products Journal, researchers frequently cite journals from a variety disciplines outside the field. Forest scientists often cite journals from fields such as botany, plant science, ecology, environmental science, chemistry, agronomy, horticulture, and genetics. What constitutes a core list of journals in a field as interdisciplinary as forestry? Do

Paul Kelsey is an Agriculture Librarian in the LSU Libraries at Louisiana State University; e-mail: pkelsey@lsu.edu. Tom Diamond is Head of Reference Services in the LSU Libraries at Louisiana State University; e-mail: notted@lsu.edu. The authors wish to thank Steve Bensman, Sigrid Kelsey, Lois KuyperRushing, and Elaine Smyth for reading the article and offering helpful suggestions for improvement. The authors also wish to thank Heather Credeur for verifying AGRICOLA Subject Category Codes. 
significant differences in citation patterns exist among assistant professors, new to the field, and associate and full professors? The present study addresses these questions.

Academic libraries continue to face a serials crisis as rising costs for journals consume ever larger amounts of collection development budgets. The Association of Research Libraries reported significant cost increases ( $8.8 \%$ per serial unit) for journal titles from 1986 to 2001, forcing many libraries to reduce serials and shift budgets to cover serials subscriptions. ${ }^{6}$ Libraries at liberal arts colleges have felt the impact of escalating costs for science journals, and many college libraries report title cancellations. ${ }^{7}$ Price increases remain particularly high for science, medical, and technical journals. Journals in the field of agriculture posted a 19.77 percent increase in average title cost from 1997 to $2001 .{ }^{8}$ Two important forestry journals, Forest Ecology and Management and Tree Physiology, posted 26.8 percent and 48.9 percent respective increases during the same time period. ${ }^{9}$ Libraries may only be able to afford ten to fifteen (or perhaps fewer, depending on budget and size of the library) of the top core journals for an academic discipline. How do librarians, who may not be subject specialists, effectively evaluate serial holdings for the sciences in today's environment of escalating journal costs?

Citation studies using bibliometrics serve as a well-established means of producing core lists of journals for academic disciplines. Bradford's Law of Scattering states that a small "nucleus of periodicals" (the core) devoted to any scientific discipline will contain a majority of articles, with the rest appearing in journals scattered in successive "zones containing the same number of articles as the nucleus."10 Citation studies typically establish a core list (or lists) by ranking journals with the highest citation counts for an academic discipline. Librarians use core lists for purchasing and cancellation decisions and to evaluate existing collections. A core list, although an important tool, should not serve as the only determining factor for evaluating serials. Indeed, the "ultimate core list" may not exist for a particular library, and journal use may vary from one group of library constituents to another. ${ }^{11}$ Core lists are most effective when used in conjunction with user surveys and other traditional tools for making serials decisions. ${ }^{12}$ Circulation data, collection development philosophies, budget considerations, the strength of a particular program at a college or university, groups of diverse users, and faculty research interests all play a significant role in serials management decisions. However, researchers continue to conduct citation studies identifying core titles to help with serials management decisions.

ISI's Journal Citation Reports (JCR) provides lists of journals for a number of academic disciplines. The database allows the user to rank titles by impact factor, total citations, and other criteria. Every journal appearing in the JCR database "is assigned to at least one subject category (or discipline) indicating a general area of science or the social sciences." ${ }^{13}$ However, JCR category lists contain inherent limitations. First, the JCR “data do not necessarily reflect a journal's importance to its own discipline because it includes citations from journals in other disciplines." ${ }^{14}$ Second, the database does not include all refereed journals important to a discipline and does not count citations from journals not indexed in the ISI database. Third, interdisciplinary journals important to a particular discipline may not be assigned to the discipline's subject category. Hence, JCR citation data are "intended to complement, not replace, traditional qualitative and subjective inputs, such as peer surveys and specialist opinions. ${ }^{15}$ Notwithstanding JCR limitations, "impact factor is the most frequently used citation measure for journal collection management" and is included on the core lists appearing in this study along with the JCR list of forestry journals. ${ }^{16}$

\section{Literature Review}

Several citation analyses in the sciences appear in the recent library literature. 
Claudia Lascar and Loren D. Mendelsohn conducted a bibliometric analysis of publications emanating from a small number of structural biologists sampled from several institutions. Citation patterns revealed the importance of interdisciplinary journals to the field. ${ }^{17}$ Angela M. Gooden analyzed the citations from thirty chemistry dissertations from the Ohio State University Department of Chemistry from 1996 to 2000 . Her study, which identified a core list of chemistry journals for collection development, examined the use of materials, dissertation subjects, types of publications cited, and the currency of materials. ${ }^{18}$ Louise S. Zipp conducted a study to provide a core list of journals for environmental geology and examined interdisciplinarity within the context of collection development. ${ }^{19}$ Zipp used intercitation analysis to create a journal network by measuring "journal-to-journal citations and thus the extent to which one title connects with the work published in another journal." ${ }^{20}$

Researchers have conducted several citation studies specific to the agricultural sciences. Luti Salisbury recently analyzed citations of publications from the entomology faculty teaching at the University of Arkansas by conducting literature searches in AGRICOLA, Cab Abstracts, and Biological Abstracts. The analysis identified the most highly cited journals, journals in which the faculty publish most frequently, and the age and type of cited publications. ${ }^{21}$ Y. M. Patil analyzed citations from articles appearing in Agropedology, a soil science journal important for Indian agricultural researchers, to establish a core list containing fortytwo journals. ${ }^{22}$ Segun Adewole analyzed citations from the subscription list of journals held in the National Animal Production Research Institute library. The study established a core list of livestock journals. ${ }^{23}$

A search of the literature uncovered a small number of cogent forestry citation studies. Steele and Stier probed the interdisciplinary relationship between the frequency a forestry article is cited and the role played by the articles cited in the author's bibliography. The authors concluded that forestry articles are cited more frequently if the works cited draw from a wider universe of interdisciplinary materials. ${ }^{24}$ Stephanie C. Haas and Kate Lee analyzed citations of faculty publications from the University of Florida's School of Forest Resources and Conservation. They applied their analysis to examining their library's forestry journal holdings and for other collection development purposes. ${ }^{25}$ Pamela J. Jakes and Andra Slimak VanDyne examined citations from the research articles of USDA Forest Service employees from one experiment station. The study identified the journals most frequently used to publish forestry research. ${ }^{26}$

The Cornell Agricultural Literature Project (CALP), conducted by researchers at Cornell University's Mann Library, established core lists of literature for several agricultural disciplines, including forestry. Steering committee experts from each discipline recommended the monographs subjected to citation analyses to create the core lists. ${ }^{27}$ The Literature of Forestry and Agroforestry, the last of the CALP series, identified core lists of the primary forestry serials. The researchers analyzed 12,500 citations, which yielded a total of 648 serial titles. The analysis resulted in a nonranked core list of sixty journals and a ranked core list, based on citation counts, containing fifty-six titles. The ranked core list shared many of the titles that appeared on the nonranked core list. The researchers counted citations from tropical and temperate forestry documents separately in order to identify journals on the lists pertinent to Third World and developed countries (with some titles listed in both categories), respectively. The researchers identified a total of forty-three journals for developed countries on the ranked core. The Cornell series is a landmark work in the agricultural sciences.

\section{Purpose of the Study}

The primary purpose of this study is to establish a current core list of the most highly cited forestry journals for use as a 
collection development tool. Goals for the study included offering a source of data to compare with the core list of primary forestry serials provided in CALP's Literature of Forestry and Agroforestry; analyzing citation differences between the three ranks of forestry faculty by providing separate core lists for assistant, associate, and full professors; compiling comparative lists of the citing journals with the most frequent publications for each faculty rank; and researching the impact of interdisciplinary journals on the resources selected by the forestry faculty. To conduct this analysis, categorical data are constructed by using the citation data and AGRICOLA Subject Category Codes (SCC). Finally, the investigators hope to provide a useful methodology for other researchers to establish similar core lists in other agricultural disciplines.

\section{Procedure}

The investigators analyzed citations from forestry faculty members teaching at selected universities in the southern United States. To be selected, a university had to offer a doctoral program in forestry as listed in Peterson's Graduate Programs in the Physical Sciences, Mathematics, Agricultural Sciences, the Environment \& Natural Sciences. ${ }^{28}$ The following seven schools were selected: Auburn University, Louisiana State University, Mississippi State University, Stephen F. Austin State University, Texas A\&M, University of Florida, and the University of Georgia. Although many of the faculty selected for the study conduct research focusing on the southern region of the United States, their research is germane to a national universe of forest scientists. Southern researchers publish in and cite a core of nationally peer-reviewed journals, and their topics (genomics, forest biometrics, silviculture, wood science, ecophysiology, etc.) span the entire spectrum of the field of forestry.

For each university, the investigators selected a representative sample comprising 50 percent of the faculty members from each rank: professor, associate professor, and assistant professor. During the summer of 2002, the investigators consulted each faculty department Web page to determine faculty status and selected every other member from each rank from the alphabetical list of faculty. In general, the sample revealed that assistant professors were in the early part of their publishing career, associate professors had been publishing in the field long enough to earn tenure and promotion, and full professors had been publishing for the longest period of time. However, it is possible that some associate professors have remained at their current status for a number of years without promotion or that an assistant professor may have publications spanning a number of years and been promoted to associate or full professor in a previous position. Nonetheless, the sample provides a representation revealing the differences in citation patterns for each faculty rank.

The study included extension and experiment station faculty but excluded emeritus professors, affiliate and adjunct faculty, faculty with joint appointments, nonfaculty extension and experiment station personnel, instructors, and visiting professors. At schools combining forestry, wildlife, and fisheries faculty (as in the case of the LSU School of Renewable Natural Resources), the authors selected only faculty clearly specializing in forestry. The selection of faculty members occurred without regard to their area of specialization within the field of forestry. The authors selected seventy-four forestry faculty members.

For each faculty member, the authors conducted literature searches in Web of Science, CABDirect, and AGRICOLA for the years 1990-2002. In most cases, Web of Science provided access to all the cited references. For journal articles indexed in CABDirect or AGRICOLA, but not in Web of Science, the authors obtained the articles from the LSU Libraries or through interlibrary borrowing. The researchers analyzed citations from academic journals published at least biannually. The study excluded annual proceedings, transactions, annals, monographs, irregular publications, trade 


\begin{tabular}{|c|c|c|c|c|c|}
\hline \multicolumn{6}{|c|}{$\begin{array}{c}\text { TABLE } 1 \\
\text { Core List of Forestry Journals } \\
\text { Ranked by Citation Counts (1990-2002) } \\
\end{array}$} \\
\hline No. & & $\begin{array}{l}\text { No. of } \\
\text { Citations }\end{array}$ & $\begin{array}{c}\text { \% of } \\
\text { Total } \\
\text { Citations }\end{array}$ & $\begin{array}{c}\text { Cumulative } \\
\% \text { of } \\
\text { Citations }\end{array}$ & $\begin{array}{l}2001 \text { JCR } \\
\text { Impact } \\
\text { Factor }\end{array}$ \\
\hline \multirow[t]{2}{*}{1} & Canadian Journal of & & & & \\
\hline & Forest Research & 772 & 4.86 & 4.86 & 1.108 \\
\hline 2 & Forest Science & 707 & 4.45 & 9.31 & 1.089 \\
\hline 3 & Forest Products Journal & 615 & 3.87 & 13.18 & 0.331 \\
\hline \multirow[t]{2}{*}{4} & Forest Ecology and & & & & \\
\hline & Management & 431 & 2.71 & 15.89 & 0.906 \\
\hline 5 & Ecology & 346 & 2.18 & 18.07 & 3.704 \\
\hline 6 & Tree Physiology & 344 & 2.17 & 20.24 & 2.309 \\
\hline \multirow[t]{2}{*}{7} & Southern Journal of & & & & \\
\hline & Applied Forestry & 318 & 2 & 22.24 & N/A \\
\hline \multirow[t]{2}{*}{8} & Soil Science Society & & & & \\
\hline & of America Journal & 265 & 1.67 & 23.91 & 1.312 \\
\hline 9 & Journal of Forestry & 264 & 1.66 & 25.57 & 0.429 \\
\hline $10-11$ & Oecologia & 245 & 1.54 & 27.11 & 2.474 \\
\hline $10-11$ & New Phytologist & 245 & 1.54 & 28.65 & 2.53 \\
\hline 12 & Plant Physiology & 240 & 1.51 & 30.16 & 5.105 \\
\hline 13 & Science & 222 & 1.4 & 31.56 & 23.329 \\
\hline \multirow[t]{2}{*}{14} & Journal of Environmental & & & & \\
\hline & Quality & 210 & 1.32 & 32.88 & 1.155 \\
\hline 15 & Silvae Genetica & 202 & 1.27 & 34.15 & 0.354 \\
\hline 16 & Plant Cell and Environment & 198 & 1.25 & 35.4 & 3.296 \\
\hline 17 & Physiologia Plantarum & 191 & 1.2 & 36.6 & 1.76 \\
\hline 18 & Holzforschung & 180 & 1.13 & 37.73 & 0.939 \\
\hline 19 & Plant and Soil & 157 & 0.99 & 38.72 & 1.229 \\
\hline 20 & Environmental Pollution & 152 & 0.96 & 39.68 & 1.56 \\
\hline 21 & Canadian Journal of Botany & 140 & 0.88 & 40.56 & 0.949 \\
\hline \multirow[t]{2}{*}{22} & Proceedings of the & & & & \\
\hline & $\begin{array}{l}\text { National Academy } \\
\text { of Sciences of the USA }\end{array}$ & 135 & 0.85 & 41.41 & 10.896 \\
\hline \multirow[t]{2}{*}{23} & Theoretical and Applied & & & & \\
\hline & Genetics & 131 & 0.82 & 42.23 & 2.438 \\
\hline $24-25$ & Wood and Fiber Science & 129 & 0.81 & 43.04 & 0.453 \\
\hline $24-25$ & Nature & 129 & 0.81 & 43.85 & 27.955 \\
\hline \multirow{2}{*}{26} & Journal of Chemical Informati & ion & & & \\
\hline & and Computer Sciences & 126 & 0.79 & 44.64 & 3.009 \\
\hline 27 & Phytopathology & 123 & 0.77 & 45.41 & 2.126 \\
\hline 28 & Genetics & 121 & 0.76 & 46.17 & 4.803 \\
\hline 29 & Water Resources Research & 114 & 0.72 & 46.89 & 1.757 \\
\hline 30 & Phytochemistry & 101 & 0.64 & 47.53 & 1.296 \\
\hline 31 & American Journal of Botany & 93 & 0.59 & 48.12 & 2.463 \\
\hline 32 & Soil Biology and Biochemistry & 88 & 0.55 & 48.67 & 1.755 \\
\hline 33 & Wetlands & 86 & 0.54 & 49.21 & 1.137 \\
\hline 34 & Ecological Applications & 84 & 0.53 & 49.74 & 3.335 \\
\hline \multirow[t]{2}{*}{35} & Journal of the American Society & & & & \\
\hline & for Horticultural Science & 82 & 0.52 & 50.26 & 0.922 \\
\hline \multicolumn{2}{|c|}{ Total Citations } & 7,986 & & & \\
\hline \multicolumn{2}{|c|}{ Total Citations for All Journals Cited 1} & 15,880 & & & \\
\hline \multicolumn{2}{|c|}{ Total Number of Journals Cited } & 1,269 & & & \\
\hline
\end{tabular}


magazines, newsletters, U.S. Department of Agriculture publications, and publications emanating from state extension and experiment stations. The authors included academic journals bearing the words annals, monographs, or transactions in their titles, such as Ecological Monographs and Annals of Botany. The authors consulted Ulrich's International Periodicals Directory, WorldCat, and AGRICOLA for biblio- graphic verification and to determine the subject content of journals.

The authors created separate Excel worksheets for each faculty rank and tabulated the cited references from each faculty publication. Each worksheet listed the journals cited, citing journals and the number of citations for each journal title. The authors combined the total citation counts of all three faculty ranks to establish a core

\begin{tabular}{|c|c|c|c|c|c|}
\hline & $\begin{array}{l}\text { Professor Cor } \\
\text { Ranked by Cit }\end{array}$ & $\begin{array}{r}\text { TABLF } \\
\text { re List of } \\
\text { tation Co }\end{array}$ & $\begin{array}{l}2 \\
\text { orestry Jc } \\
\text { nts }(1990\end{array}$ & $\begin{array}{l}\text { purnals } \\
\text {-2002) }\end{array}$ & \\
\hline No & & $\begin{array}{l}\text { No. of } \\
\text { Citations }\end{array}$ & $\begin{array}{c}\text { \% of } \\
\text { Total } \\
\text { Citations }\end{array}$ & $\begin{array}{c}\text { Cumulative } \\
\% \text { of } \\
\text { Citations }\end{array}$ & $\begin{array}{l}2001 \text { JCR } \\
\text { Impact } \\
\text { Factor }\end{array}$ \\
\hline 1 & Forest Products Journal & 354 & 5.15 & 5.15 & 0.331 \\
\hline 2 & Canadian Journal of & & & & \\
\hline & Forest Research & 338 & 4.92 & 10.07 & 1.108 \\
\hline 3 & Forest Science & 332 & 4.83 & 14.9 & 1.089 \\
\hline 4 & Southern Journal of & & & & \\
\hline & Applied Forestry & 196 & 2.85 & 17.75 & $\mathrm{~N} / \mathrm{A}$ \\
\hline 5 & Forest Ecology and Management & 194 & 2.82 & 20.57 & 0.906 \\
\hline 6 & Ecology & 182 & 2.65 & 23.22 & 3.704 \\
\hline 7 & Soil Science Society of & & & & \\
\hline & America Journal & 168 & 2.45 & 25.67 & 1.312 \\
\hline 8 & Holzforschung & 141 & 2.05 & 27.72 & 0.939 \\
\hline 9 & Theoretical and Applied Genetics & 121 & 1.76 & 29.48 & 2.438 \\
\hline 10 & Silvae Genetica & 105 & 1.53 & 31.01 & 0.354 \\
\hline 11 & Journal of Forestry & 98 & 1.43 & 32.44 & 0.429 \\
\hline 12 & Tree Physiology & 94 & 1.37 & 33.81 & 2.309 \\
\hline 13 & Wood and Fiber Science & 91 & 1.32 & 35.13 & 0.453 \\
\hline 14 & Genetics & 90 & 1.31 & 36.44 & 4.803 \\
\hline 15 & Phytochemistry & 89 & 1.3 & 37.74 & 1.296 \\
\hline 16 & Plant Physiology & 86 & 1.25 & 38.99 & 5.105 \\
\hline 17 & $\begin{array}{l}\text { Journal of Chemical Information } \\
\text { and Computer Sciences }\end{array}$ & 78 & 1.14 & 40.13 & 3.009 \\
\hline 18 & Wetlands & 78 & 1.14 & 41.27 & 1.137 \\
\hline 19 & Science & 77 & 1.12 & 42.39 & 23.329 \\
\hline 20 & Journal of Environmental Quality & 75 & 1.09 & 43.48 & 1.155 \\
\hline 21 & American Journal of Botany & 69 & 1 & 44.48 & 2.463 \\
\hline 22 & Physiologia Plantarum & 67 & 0.98 & 45.46 & 1.76 \\
\hline 23 & South African Forestry Journal & 63 & 0.92 & 46.38 & $\mathrm{~N} / \mathrm{A}$ \\
\hline 24 & Oecologia & 59 & 0.86 & 47.24 & 2.474 \\
\hline 25 & Plant Cell and Environment & 58 & 0.84 & 48.08 & 3.296 \\
\hline 26 & Plant Cell Reports & 56 & 0.82 & 48.9 & 1.375 \\
\hline 27 & Soil Biology and Biochemistry & 56 & 0.82 & 49.72 & 1.755 \\
\hline 28 & American Midland Naturalist & 55 & 0.8 & 50.52 & 0.494 \\
\hline Tot & al Citations & 3,470 & & & \\
\hline Tot & al Citations for Professors & 6,870 & & & \\
\hline Tot & al Number of Journals Cited & 696 & & & \\
\hline
\end{tabular}




\section{TABLE 3}

Associate Professor Core List of Forestry Journals Ranked by Citation Counts (1990-2002)

\begin{tabular}{|c|c|c|c|c|c|}
\hline No. & & $\begin{array}{c}\text { No. of } \\
\text { Citations }\end{array}$ & \multirow[t]{2}{*}{$\begin{array}{c}\% \text { of } \\
\text { Total } \\
\text { Citations }\end{array}$} & \multirow[t]{2}{*}{$\begin{array}{c}\text { Cumulative } \\
\% \text { of } \\
\text { Citations } \\
\end{array}$} & \multirow[t]{2}{*}{$\begin{array}{c}2001 \text { JCR } \\
\text { Impact } \\
\text { Factor }\end{array}$} \\
\hline 1 & Canadian Journal of & & & & \\
\hline & Forest Research & 266 & 4.8 & 4.8 & 1.108 \\
\hline 2 & Forest Science & 256 & 4.62 & 9.42 & 1.089 \\
\hline 3 & Forest Products Journal & 225 & 4.06 & 13.48 & 0.331 \\
\hline 4 & Tree Physiology & 162 & 2.92 & 16.4 & 2.309 \\
\hline 5 & New Phytologist & 143 & 2.58 & 18.98 & 2.53 \\
\hline 6 & Journal of Forestry & 124 & 2.24 & 21.22 & 0.429 \\
\hline 7 & Environmental Pollution & 111 & 2 & 23.22 & 1.56 \\
\hline 8 & Forest Ecology and Management & 108 & 1.95 & 25.17 & 0.906 \\
\hline 9 & Southern Journal of Applied Forestry & 105 & 1.89 & 27.06 & N/A \\
\hline 10 & Journal of Environmental Quality & 103 & 1.86 & 28.92 & 1.155 \\
\hline 11 & Plant Physiology & 92 & 1.66 & 30.58 & 5.105 \\
\hline 12 & Water Resources Research & 90 & 1.62 & 32.2 & 1.757 \\
\hline 13 & Science & 87 & 1.57 & 33.77 & 23.329 \\
\hline 14 & Phytopathology & 84 & 1.51 & 35.28 & 2.126 \\
\hline 15 & Canadian Journal of Botany & 65 & 1.17 & 36.45 & 0.949 \\
\hline \multirow[t]{2}{*}{16} & Soil Science Society of & & & & \\
\hline & America Journal & 63 & 1.14 & 37.59 & 1.312 \\
\hline 17 & Plant Cell and Environment & 60 & 1.08 & 38.67 & 3.296 \\
\hline \multirow{2}{*}{18} & Proceedings of the National Academ & & & & \\
\hline & of Sciences of the USA & 60 & 1.08 & 39.75 & 10.896 \\
\hline 19 & Ecology & 58 & 1.05 & 40.8 & 3.704 \\
\hline 20 & Gene & 52 & 0.94 & 41.74 & 3.041 \\
\hline 21 & Physiologia Plantarum & 52 & 0.94 & 42.68 & 1.76 \\
\hline 22 & Oecologia & 50 & 0.9 & 43.58 & 2.474 \\
\hline \multirow[t]{2}{*}{23} & Journal of Chemical Information & & & & \\
\hline & and Computer Sciences & 48 & 0.87 & 44.45 & 3.009 \\
\hline 24 & Water, Air, and Soil Pollution & 45 & 0.81 & 45.26 & 0.772 \\
\hline \multirow[t]{2}{*}{25} & Molecular Plant-Microbe & & & & \\
\hline & Interactions & 43 & 0.78 & 46.04 & 3.855 \\
\hline \multirow[t]{2}{*}{26} & Journal of the American Society & & & & \\
\hline & for Horticultural Science & 41 & 0.74 & 46.78 & 0.922 \\
\hline 27 & Silvae Genetica & 40 & 0.72 & 47.5 & 0.354 \\
\hline 28 & Holzforschung & 39 & 0.7 & 48.2 & 0.939 \\
\hline 29 & Plant and Soil & 39 & 0.7 & 48.9 & 1.229 \\
\hline 30 & Molecular \& General Genetics & 38 & 0.69 & 49.59 & 2.472 \\
\hline & Applied and Environmental & & & & \\
\hline & Microbiology & 36 & 0.65 & 50.24 & 3.688 \\
\hline 32 & Journal. American Chemical Society & ty 36 & 0.65 & 50.89 & 6.079 \\
\hline \multicolumn{2}{|r|}{$\begin{array}{ll}\text { Total Citations } & 2\end{array}$} & 2,821 & & & \\
\hline \multicolumn{2}{|r|}{ Total Citations for Associate Professors 5} & 5,547 & & & \\
\hline \multicolumn{2}{|r|}{ Total Number of Journals Cited } & 709 & & & \\
\hline
\end{tabular}


TABLE 4

Assistant Professor Core List of Forestry Journals Ranked by Citation Counts (1990-2002)

\begin{tabular}{|c|c|c|c|c|c|}
\hline No. & & $\begin{array}{l}\text { No. of } \\
\text { Citations }\end{array}$ & $\begin{array}{c}\% \text { of } \\
\text { Total } \\
\text { Citations }\end{array}$ & $\begin{array}{c}\text { Cumulative } \\
\% \text { of } \\
\text { Citations }\end{array}$ & $\begin{array}{c}2001 \text { JCR } \\
\text { Impact } \\
\text { Factor }\end{array}$ \\
\hline 1 & $\begin{array}{l}\text { Canadian Journal of } \\
\text { Forest Research }\end{array}$ & 168 & 4.85 & 4.85 & 1.108 \\
\hline 2 & Oecologia & 136 & 3.93 & 8.78 & 2.474 \\
\hline 3 & Forest Ecology and Management & 129 & 3.73 & 12.51 & 0.906 \\
\hline 4 & Forest Science & 119 & 3.44 & 15.95 & 1.089 \\
\hline 5 & Ecology & 106 & 3.06 & 19.01 & 3.704 \\
\hline 6 & Tree Physiology & 88 & 2.54 & 21.55 & 2.309 \\
\hline 7 & Plant Cell and Environment & 80 & 2.31 & 23.86 & 3.296 \\
\hline 8 & Plant and Soil & 75 & 2.17 & 26.03 & 1.229 \\
\hline 9 & New Phytologist & 73 & 2.11 & 28.14 & 2.53 \\
\hline 10 & Physiologia Plantarum & 72 & 2.08 & 30.22 & 1.76 \\
\hline 11 & Plant Physiology & 62 & 1.79 & 32.01 & 5.105 \\
\hline 12 & Science & 58 & 1.67 & 33.68 & 23.329 \\
\hline 13 & Silvae Genetica & 57 & 1.65 & 35.33 & 0.772 \\
\hline 14 & Water Air and Soil Pollution & 57 & 1.65 & 36.98 & 0.354 \\
\hline 15 & Ecological Applications & 51 & 1.47 & 38.45 & 3.335 \\
\hline 16 & Nature & 50 & 1.44 & 39.89 & 27.955 \\
\hline 17 & Functional Ecology & 49 & 1.41 & 41.3 & 2.144 \\
\hline 18 & Global Change Biology & 43 & 1.24 & 42.54 & 3.537 \\
\hline 19 & Journal of Forestry & 42 & 1.21 & 43.75 & 0.429 \\
\hline 20 & Forest Products Journal & 36 & 1.04 & 44.79 & 1.42 \\
\hline 21 & Trees-Structure and Function & 36 & 1.04 & 45.83 & 0.331 \\
\hline 22 & Ecological Monographs & 34 & 0.98 & 46.81 & 1.312 \\
\hline \multirow[t]{2}{*}{23} & Soil Science Society of & & & & \\
\hline & America Journal & 34 & 0.98 & 47.79 & 5.551 \\
\hline 24 & Agroforestry Systems & 33 & 0.95 & 48.74 & 1.153 \\
\hline 25 & Journal of Environmental Quality & 32 & 0.92 & 49.66 & 1.155 \\
\hline 26 & Forstarchiv & 30 & 0.87 & 50.53 & N/A \\
\hline \multicolumn{3}{|c|}{$\begin{array}{lc}\text { Total Citations } & 1,750\end{array}$} & & & \\
\hline \multicolumn{3}{|c|}{ Total Citations for Assistant Professors 3,463 } & & & \\
\hline \multicolumn{2}{|r|}{ Total Number of Journals Cited } & 475 & & & \\
\hline
\end{tabular}

list of the most frequently cited journals for the field of forestry. The researchers established a core list for each faculty designation by ranking the journals with the highest citation counts for each faculty group. The authors counted a total of 15,880 citations from a universe of 1,269 journal titles to arrive at the core list of forestry journals. The forestry faculty selected for the study published a total of 969 articles in 194 journals. Journals with citations comprising the cumulative top 50 percent appear on the core list.
The National Agriculture Library (NAL) assigns AGRICOLA SCC to journals and articles indexed in NAL. The subject codes are specific to agriculture and provide a similar function to the Library of Congress Subject Headings. Interdisciplinary journals are assigned a primary subject code and additional secondary code(s). The subject codes serve to identify the primary topic of a journal or a journal that is interdisciplinary in nature. The authors identified subject codes for the universe of journals in the study by consulting AGRICOLA. (See table 10.) 


\begin{tabular}{|c|c|c|c|c|}
\hline \multicolumn{5}{|c|}{$\begin{array}{l}\text { TABLE } 5 \\
\text { Combined List of Core Forestry Journals } \\
\text { Cited for Each Faculty Rank (1990-2002) } \\
\end{array}$} \\
\hline No. & $\begin{array}{c}\text { Composite } \\
\text { Rank }\end{array}$ & $\begin{array}{c}\text { Professors } \\
\text { Table } 2\end{array}$ & $\begin{array}{c}\text { Associates } \\
\text { Table } 3\end{array}$ & $\begin{array}{c}\text { Assistants } \\
\text { Table } 4\end{array}$ \\
\hline Canadian Journal of Forest Research & 1 & 2 & 1 & 1 \\
\hline Forest Science & 2 & 3 & 2 & 4 \\
\hline Forest Products Journal & 3 & 1 & 3 & 20 \\
\hline Forest Ecology and Management & 4 & 5 & 8 & 3 \\
\hline Ecology & 5 & 6 & 19 & 5 \\
\hline Tree Physiology & 6 & 12 & 4 & 6 \\
\hline Southern Journal of Applied Forestry & 7 & 4 & 9 & N/A \\
\hline Soil Science Society of America Journal & 8 & 7 & 16 & 23 \\
\hline Journal of Forestry & 9 & 11 & 6 & 19 \\
\hline Oecologia & 10 & 24 & 22 & 2 \\
\hline New Phytologist & 11 & N/A & 5 & 9 \\
\hline Plant Physiology & 12 & 16 & 11 & 11 \\
\hline Science & 13 & 19 & 13 & 12 \\
\hline Journal of Environmental Quality & 14 & 20 & 10 & 25 \\
\hline Silvae Genetica & 15 & 10 & 27 & 13 \\
\hline Plant Cell and Environment & 16 & 25 & 17 & 7 \\
\hline Physiologia Plantarum & 17 & 22 & 21 & 10 \\
\hline Holzforschung & 18 & 8 & 28 & N/A \\
\hline Plant and Soil & 19 & N/A & 29 & 8 \\
\hline Environmental Pollution & 20 & N/A & 7 & N/A \\
\hline Canadian Journal of Botany & 21 & N/A & 15 & N/A \\
\hline \multicolumn{5}{|l|}{ Proceedings of the National Academy } \\
\hline of Sciences of the USA & 22 & N/A & 18 & N/A \\
\hline Theoretical and Applied Genetics & 23 & 9 & $\mathrm{~N} / \mathrm{A}$ & $\mathrm{N} / \mathrm{A}$ \\
\hline Wood and Fiber Science & 24 & 13 & N/A & N/A \\
\hline Nature & 25 & N/A & $\mathrm{N} / \mathrm{A}$ & 16 \\
\hline \multicolumn{5}{|l|}{ Journal of Chemical Information } \\
\hline and Computer Sciences & 26 & 17 & 23 & N/A \\
\hline Phytopathology & 27 & N/A & 14 & N/A \\
\hline Genetics & 28 & 14 & N/A & $\mathrm{N} / \mathrm{A}$ \\
\hline Water Resources Research & 29 & $\mathrm{~N} / \mathrm{A}$ & 12 & $\mathrm{~N} / \mathrm{A}$ \\
\hline Phytochemistry & 30 & 15 & N/A & N/A \\
\hline American Journal of Botany & 31 & 21 & $\mathrm{~N} / \mathrm{A}$ & N/A \\
\hline Soil Biology and Biochemistry & 32 & 27 & N/A & N/A \\
\hline Wetlands & 33 & 18 & N/A & N/A \\
\hline Ecological Applications & 34 & N/A & N/A & 15 \\
\hline \multicolumn{5}{|l|}{ Journal of the American Society } \\
\hline for Horticultural Science & 35 & N/A & 26 & N/A \\
\hline Ecological Monographs & 36 & N/A & $\mathrm{N} / \mathrm{A}$ & 22 \\
\hline \multicolumn{5}{|l|}{ Journal of the American Chemical } \\
\hline Society and Computer Sciences & $38(\mathrm{~T})$ & N/A & 32 & N/A \\
\hline South African Forestry Journal & $38(\mathrm{~T})$ & 23 & N/A & N/A \\
\hline Water, Air, and Soil Pollution & 42 & N/A & 24 & 14 \\
\hline Trees-Structure and Function & $44(\mathrm{~T})$ & N/A & N/A & 21 \\
\hline Agroforestry Systems & 45 & $\mathrm{~N} / \mathrm{A}$ & $\mathrm{N} / \mathrm{A}$ & 24 \\
\hline Functional Ecology & 46 & N/A & $\mathrm{N} / \mathrm{A}$ & 17 \\
\hline American Midland Naturalist & 48 & 28 & N/A & N/A \\
\hline
\end{tabular}




\begin{tabular}{|c|c|c|c|c|}
\hline \multicolumn{5}{|c|}{$\begin{array}{l}\text { TABLE } 5 \text { (CONTINUED) } \\
\text { Combined List of Core Forestry Journals } \\
\text { Cited for Each Faculty Rank (1990-2002) }\end{array}$} \\
\hline No. & $\begin{array}{c}\text { Composite } \\
\text { Rank }\end{array}$ & $\begin{array}{l}\text { Professors } \\
\text { Table } 2\end{array}$ & $\begin{array}{l}\text { Associates } \\
\text { Table } 3\end{array}$ & $\begin{array}{c}\text { Assistants } \\
\text { Table } 4\end{array}$ \\
\hline Plant Cell Reports & 49 & 26 & N/A & N/A \\
\hline Gene & $52(\mathrm{~T})$ & N/A & 20 & N/A \\
\hline Molecular \& General Genetics & $55(\mathrm{~T})$ & N/A & 30 & N/A \\
\hline Global Change Biology & $61(\mathrm{~T})$ & N/A & N/A & 18 \\
\hline Applied and Environmental Microbic & logy 67 & $\mathrm{~N} / \mathrm{A}$ & 31 & N/A \\
\hline Molecular Plant-Microbe Interactior & ns $72(\mathrm{~T})$ & $\mathrm{N} / \mathrm{A}$ & 25 & N/A \\
\hline $\begin{array}{l}\text { Forstarchiv } \\
\mathrm{T}=\mathrm{Tie}\end{array}$ & 92(T) & N/A & $\mathrm{N} / \mathrm{A}$ & 26 \\
\hline
\end{tabular}

\section{Results}

Ten tables display the results of the citation analysis. Table 1 includes the core list of forestry journals for all faculty members selected for the study ranked by citation counts. Thirty-five journals comprise the top 50 percent of the total cumulative citations. The top nine journals account for over 25 percent of the core journal titles and produce over 25 percent of the total citations. The core list journal titles account for 7,986 citations (50.26\%) of the total of 15,880 citations. The results conform to Bradford's law of scattering.

Tables 2 through 4 display the core lists of journals cited by each faculty rank. Table 2 reveals that the professors generated a total of 3,470 citations from a core list of twenty-eight journals. These journals account for over 50 percent of the cumulative citations and represent four percent of all journals cited by the professors. The top seven journals account for over 25 percent of the total citations. In table 3, thirty-two titles represent the core list of journals cited by the associate professors. These thirty-two titles account for 50 percent of the cumulative citations and represent 4.5 percent of all journals cited by the associate professors. The top eight journals account for over 25 percent of the total citations. In table 4 , twentysix titles constitute the core list of journals cited by the assistant professors. These twenty-six titles account for over 50 percent of the total citations and rep- resent 5.5 percent of all journals cited by the assistant professors. The top eight journals represent over 25 percent of the total citations.

Table 5 combines the results from the core lists for each faculty designation (tables 2, 3, and 4) and includes the composite ranking from the universe of 1,269 journals. Table 5 includes fifteen journals, such as Trees-Structure and Function and Agroforestry Systems, that appear on the separate core lists for the three faculty designations, but not on the combined core list (table 1). Fifteen journals, including Forest Products Journal and Silvae Genetica, appear on all three faculty core lists. Six journals, including New Phytologist and Plant and Soil, appear variously on two of the three core lists. Twenty-nine journals appear on only one of the three core lists for each faculty designation.

Tables 6 and 7 present tabulated data for the citing journals or the journals in which the faculty published their articles. Table 6 shows the list of citing journals containing the top 50 percent cumulative publications, ranked by number of publications, for each faculty designation. The table contains eight journals listed for both the professors and assistant professors; twelve journals are listed for the associate professors.

The top two journals listed for professors account for 25.64 percent of the total number of published articles; the three 


\section{TABLE 6}

Citing Journals Ranked by Number of Publications (1990-2002)

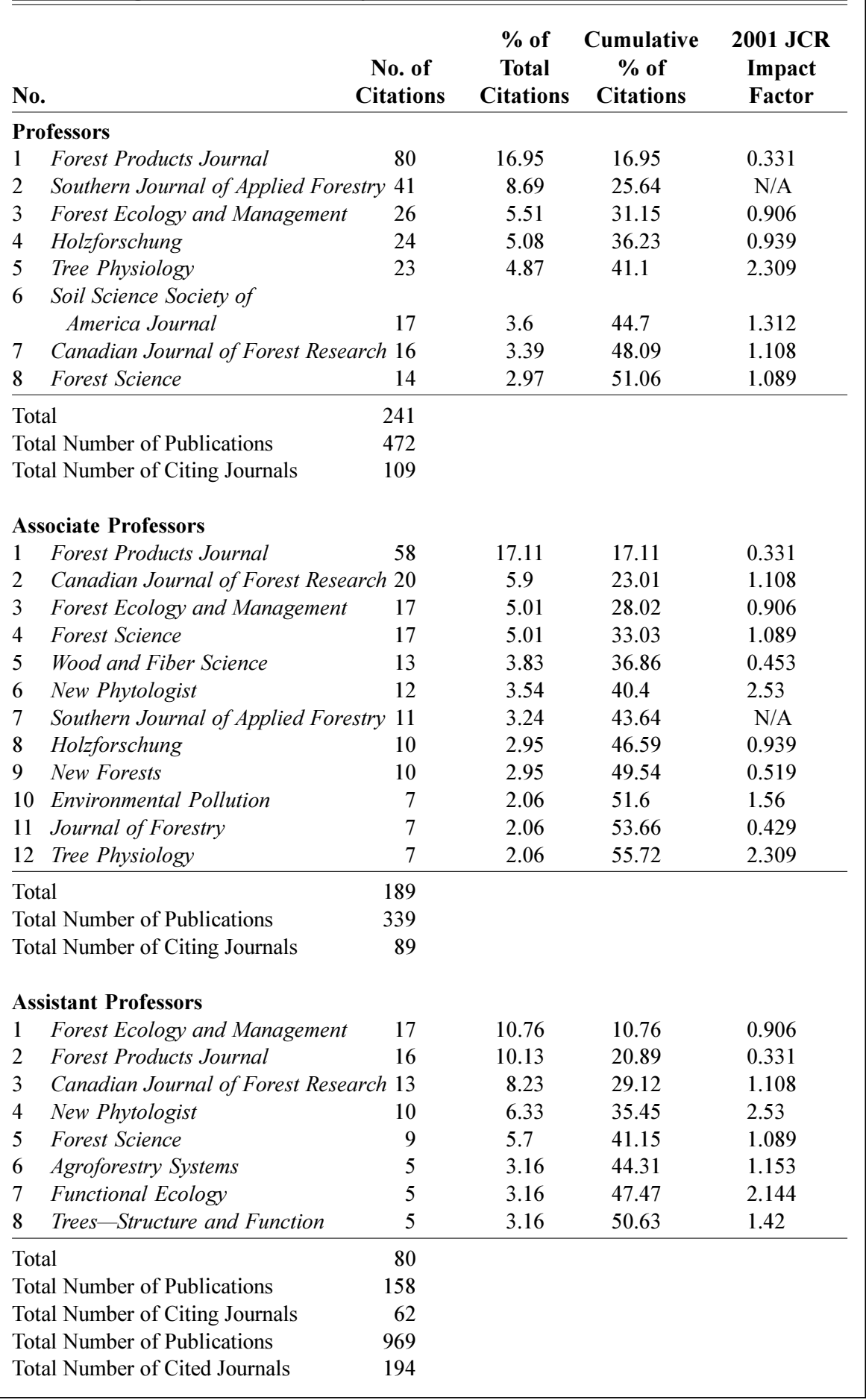


top journals for associate and assistant professors account for 28.02 percent and 29.12 percent of the number of published articles for these respective groups. The faculty published 969 articles in 194 journals. Table 7 combines all the citing journals listed for each rank in table 6. Eight journal titles appear on only one of the three faculty core lists. Four journals appear variously for two of the faculty designations, and faculty in all ranks published articles in four journals.

Table 8 summarizes the data for the journals cited and the citing journals according to faculty rank. A total of seventyfour faculty members cited 15,880 articles published in 1,269 journals. The faculty published 969 articles in 194 journals. Faculty members published an average number of 13.09 articles. Professors published 14.75 articles per faculty member, the highest of the three groups, whereas the associate professors published 14.13 articles per faculty member and the assistant professors 8.78 articles per faculty member.

Table 9 compares LSU's study with the CALP core list of forestry journals for developed countries and includes the JCR list of forestry journals. The current study identified a ranked list of thirty-five core journals compared to the CALP list of forty-three ranked journals for developed countries receiving the highest number of citations. For comparative purposes, CALP's core list is used for developed countries because the core titles produced in the present analysis do not appear on CALP's Third World core list. Four additional titles for developed countries appeared on the nonranked CALP core list of sixty titles for developed and Third World countries. The table shows that twenty-one CALP titles $(48.84 \%$ of the CALP core) appear on the core list of titles in the present study. The current study identified twelve titles ( $34.29 \%$ of the LSU core), including Tree Physiology and Journal of Environmental Quality, that did not appear on the CALP core lists. Table 9 lists the top thirty-five journals from the present study first, followed by the ranked CALP titles not appearing on the LSU core and the two remaining noncore forestry titles from CALP. For comparative purposes, the table lists the LSU, CALP, and JCR numerical rankings. Twenty-six journals from the LSU core list

TABLE 7

Combined List of Citing Journals for Each Faculty Rank (1990-2002)

\begin{tabular}{lccc}
\hline Professors & $\begin{array}{c}\text { Associates } \\
\text { Table 6 }\end{array}$ & $\begin{array}{c}\text { Assistants } \\
\text { Table 6 }\end{array}$ \\
\hline Forest Products Journal & 1 & 1 & 2 \\
Forest Ecology and Management & 3 & 3 & 1 \\
Southern Journal of Applied Forestry & 2 & 7 & N/A \\
Canadian Journal of Forest Research & 7 & 2 & 3 \\
Forest Science & 8 & 4 & 5 \\
Holzforschung & 4 & 8 & N/A \\
Tree Physiology & 5 & 12 & N/A \\
Wood and Fiber Science & N/A & 5 & N/A \\
New Phytologist & N/A & 6 & 4 \\
Soil Science Society of America Journal & 6 & N/A & N/A \\
Journal of Forestry & N/A & 11 & N/A \\
New Forests & N/A & 9 & N/A \\
Environmental Pollution & N/A & 10 & N/A \\
Trees-Structure and Function & N/A & N/A & 8 \\
Agroforestry Systems & N/A & N/A & 6 \\
Functional Ecology & N/A & N/A & 7 \\
\hline
\end{tabular}




\begin{tabular}{|c|c|c|c|c|c|c|c|}
\hline \multicolumn{8}{|c|}{$\begin{array}{c}\text { TABLE } 8 \\
\text { Summary of Journals Cited and Citing Journals for Each Faculty Rank } \\
\end{array}$} \\
\hline & Professor & $\begin{array}{l}\% \text { of } \\
\text { Total }\end{array}$ & Associate & $\begin{array}{l}\% \text { of } \\
\text { Total }\end{array}$ & Assistant & $\begin{array}{l}\text { \% of } \\
\text { Total }\end{array}$ & Total \\
\hline Number of Faculty & 32 & & 24 & & 18 & & 74 \\
\hline \multicolumn{8}{|l|}{ Journals Cited: } \\
\hline Citations & 6,870 & 43.26 & 5,547 & 34.93 & 3,463 & 21.81 & 15,880 \\
\hline Number of Journals & 696 & 37.02 & 709 & 37.71 & 475 & 25.27 & $1,269 *$ \\
\hline \multicolumn{8}{|l|}{ Citing Journals: } \\
\hline Number of Publications & 472 & 48.71 & 339 & 34.98 & 158 & 16.31 & 969 \\
\hline Number of Citing Journals & s 109 & 41.92 & 89 & 34.23 & 62 & 23.85 & $194 *$ \\
\hline \multicolumn{8}{|c|}{ Average No. of Publications } \\
\hline Per Faculty Member & 14.75 & & 14.13 & & 8.78 & & 13.09 \\
\hline
\end{tabular}

appear in the JCR database, but not in the subject category list for forestry. One journal, Southern Journal of Applied Forestry, does not appear at all in the JCR database.

Table 10 categorizes the universe of journals according to AGRICOLASCC assignment. The investigators used WilsonWeb's AGRICOLA database to extract the journal codes. A total of 576 journals received code numbers out of a universe of 1,269 journals. The 693 journals not assigned code numbers only represent 16.44 percent of total citations. The table categories include forestry code-only assignments, forestry and secondary codes, and journals only assigned nonforestry codes. The table notes only the primary subject code assigned to each journal, although multiple codes may have been assigned. Fifty-two journals, representing 22.36 percent of the total citations, received a single forestry code. Fourteen journals, representing 7.35 percent of the total citations, received a combination of forestry and nonforestry codes. A total of 510 nonforestry coded journals accounted for 53.85 percent of the total citations. Within the nonforestry code(s), the Auxiliary Disciplines SCC, which includes the Life Sciences SCC, accounted for the largest number of journals (245) and citations $(3,933)$. The information in table 10 is useful for illustrating the broad spectrum of subjects covered by these journals and shows the percentage of citations for particular subjects within the codes.

\section{Analysis}

The study produced a core list of journals with significant differences from the CALP study. Twelve titles appear only on the LSU core list, including Journal of Environmental Quality, Proceedings of the $\mathrm{Na}$ tional Academy of Sciences of the USA, Theoretical and Applied Genetics, Phytopathology, and Genetics. All of these titles are interdisciplinary in nature. The presence of Theoretical and Applied Genetics and Genet$i c s$ on the core list points to the recent tendency in the sciences to conduct more genetic research. Many of the journals cited in the LSU study received different ranks from the CALP titles. For example, Forest Ecology and Management ranked fourth in the LSU study versus twentyfirst in the CALP list. Similarly, the current study ranked Forest Products Journal third compared to a ranking of eighth in the CALP list. The impact factor appearing in the JCR for Forest Products Journal increased from .299 in 1998 to .331 in 2001, which corresponds to the higher place- 


\begin{tabular}{|c|c|c|c|c|}
\hline \multicolumn{5}{|c|}{$\begin{array}{c}\text { TABLE } 9 \\
\text { Core List of Forestry Journals } \\
\text { Research Project Comparisons } \\
\end{array}$} \\
\hline No. & $\begin{array}{l}\text { LSU } \\
2002 \\
\text { Rank }\end{array}$ & $\begin{array}{c}\text { Cornell } \\
1994 \\
\text { Rank (1) } \\
\end{array}$ & $\begin{array}{c}\text { JCR } \\
2001 \\
\text { Rank (3) }\end{array}$ & $\begin{array}{l}\text { JCR } 2001 \\
\text { Impact } \\
\text { Factor } \\
\end{array}$ \\
\hline Canadian Journal of Forest Research & 1 & 2 & 7 & 1.108 \\
\hline Forest Science & 2 & 1 & 8 & 1.089 \\
\hline Forest Products Journal & 3 & 8 & 26 & 0.331 \\
\hline Forest Ecology and Management & 4 & 21 & 11 & 0.906 \\
\hline Ecology & 5 & 6 & $\mathrm{~N} / \mathrm{A}$ & 3.704 \\
\hline Tree Physiology & 6 & N/A & 1 & 2.309 \\
\hline Southern Journal of Applied Forestry & 7 & 9 & N/A & $\mathrm{N} / \mathrm{A}$ \\
\hline Soil Science Society of America Journal & 8 & 16 & N/A & 1.312 \\
\hline Journal of Forestry & 9 & 4 & 22 & 0.429 \\
\hline Oecologia & 10 & 12 & $\mathrm{~N} / \mathrm{A}$ & 2.474 \\
\hline New Phytologist & 11 & 11 & $\mathrm{~N} / \mathrm{A}$ & 2.53 \\
\hline Plant Physiology & 12 & 3 & N/A & 5.105 \\
\hline Science & 13 & 15 & N/A & 23.329 \\
\hline Journal of Environmental Quality & 14 & $\mathrm{~N} / \mathrm{A}$ & $\mathrm{N} / \mathrm{A}$ & 1.155 \\
\hline Silvae Genetica & 15 & 10 & 25 & 0.354 \\
\hline Plant Cell and Environment & 16 & 24 & $\mathrm{~N} / \mathrm{A}$ & 3.296 \\
\hline Physiologia Plantarum & 17 & 7 & N/A & 1.76 \\
\hline Holzforschung & 18 & $X(2)$ & 10 & 0.939 \\
\hline Plant and Soil & 19 & 28 & $\mathrm{~N} / \mathrm{A}$ & 1.229 \\
\hline Environmental Pollution & 20 & 42 & N/A & 1.56 \\
\hline Canadian Journal of Botany & 21 & 5 & N/A & 0.949 \\
\hline \multicolumn{5}{|l|}{ Proceedings of the National Academy } \\
\hline of Sciences of the USA & 22 & N/A & N/A & 10.896 \\
\hline Theoretical and Applied Genetics & 23 & N/A & $\mathrm{N} / \mathrm{A}$ & 2.438 \\
\hline Wood and Fiber Science & 24 & $\mathrm{X}(2)$ & 20 & 0.453 \\
\hline Nature & 25 & 30 & N/A & 27.955 \\
\hline \multicolumn{5}{|l|}{ Journal of Chemical Information } \\
\hline and Computer Sciences & 26 & N/A & $\mathrm{N} / \mathrm{A}$ & 3.009 \\
\hline Phytopathology & 27 & N/A & $\mathrm{N} / \mathrm{A}$ & 2.126 \\
\hline Genetics & 28 & $\mathrm{~N} / \mathrm{A}$ & N/A & 4.803 \\
\hline Water Resources Research & 29 & N/A & N/A & 1.757 \\
\hline Phytochemistry & 30 & N/A & N/A & 1.296 \\
\hline American Journal of Botany & 31 & 13 & $\mathrm{~N} / \mathrm{A}$ & 2.463 \\
\hline Soil Biology and Biochemistry & 32 & $\mathrm{~N} / \mathrm{A}$ & $\mathrm{N} / \mathrm{A}$ & 1.755 \\
\hline Wetlands & 33 & $\mathrm{~N} / \mathrm{A}$ & N/A & 1.137 \\
\hline Ecological Applications & 34 & N/A & N/A & 3.335 \\
\hline \multicolumn{5}{|l|}{ Journal of the American Society } \\
\hline for Horticultural Science & 35 & 14 & $\mathrm{~N} / \mathrm{A}$ & 0.922 \\
\hline Water, Air, and Soil Pollution & $42(\mathrm{~T})$ & 17 & N/A & 0.772 \\
\hline Journal of Experimental Botany & $62(\mathrm{~T})$ & 18 & N/A & 2.433 \\
\hline Annual Review of Plant Physiology & $126(\mathrm{~T})$ & 19 & N/A & 17.372 \\
\hline Annals of Botany & $323(\mathrm{~T})$ & 20 & $\mathrm{~N} / \mathrm{A}$ & 1.352 \\
\hline Botanical Gazette & $126(\mathrm{~T})$ & 22 & $\mathrm{~N} / \mathrm{A}$ & N/A \\
\hline Journal of Horticultural Science & $465(\mathrm{~T})$ & 23 & N/A & $\mathrm{N} / \mathrm{A}$ \\
\hline New Zealand Journal of Forestry Science & $51(\mathrm{~T})$ & 25 & N/A & $\mathrm{N} / \mathrm{A}$ \\
\hline Tappi Journal & $38(\mathrm{~T})$ & 26 & N/A & 0.369 \\
\hline
\end{tabular}




\begin{tabular}{|c|c|c|c|c|}
\hline \multicolumn{5}{|c|}{$\begin{array}{c}\text { TABLE } 9 \text { (CONTINUED) } \\
\text { Core List of Forestry Journals } \\
\text { Research Project Comparisons } \\
\end{array}$} \\
\hline No. & $\begin{array}{l}\text { LSU } \\
2002 \\
\text { Rank }\end{array}$ & $\begin{array}{c}\text { Cornell } \\
1994 \\
\text { Rank (1) }\end{array}$ & $\begin{array}{c}\text { JCR } \\
2001 \\
\text { Rank (3) }\end{array}$ & $\begin{array}{l}\text { JCR } 2001 \\
\text { Impact } \\
\text { Factor }\end{array}$ \\
\hline Australian Journal of Botany & $165(\mathrm{~T})$ & 27 & N/A & 0.671 \\
\hline Forestry Chronicle & $69(\mathrm{~T})$ & 28 & 24 & 0.402 \\
\hline Forestry & $90(\mathrm{~T})$ & 31 & 18 & 0.52 \\
\hline Journal of Applied Ecology & $47(\mathrm{~T})$ & 32 & $\mathrm{~N} / \mathrm{A}$ & 2.937 \\
\hline HortScience & $72(\mathrm{~T})$ & 33 & N/A & 0.542 \\
\hline Australian Journal of Plant Physiology & $81(\mathrm{~T})$ & 34 & N/A & 1.562 \\
\hline Ecological Monographs & $36(\mathrm{~T})$ & 35 & N/A & 5.551 \\
\hline Journal of Ecology & $38(\mathrm{~T})$ & 36 & $\mathrm{~N} / \mathrm{A}$ & 2.291 \\
\hline Planta; Archiv fur Wissenschaftliche & 37 & 37 & N/A & 3.349 \\
\hline Acta Horticulturae & $\mathrm{N} / \mathrm{A}$ & $38(\mathrm{~T})$ & N/A & N/A \\
\hline Journal of Wildlife Management & $107(\mathrm{~T})$ & $38(\mathrm{~T})$ & N/A & 1.593 \\
\hline Agronomy Journal & $69(\mathrm{~T})$ & 40 & N/A & 0.88 \\
\hline BioScience & $52(\mathrm{~T})$ & 41 & $\mathrm{~N} / \mathrm{A}$ & 3.295 \\
\hline \multicolumn{5}{|l|}{ Annual Review of Ecology } \\
\hline and Systematics & $65(\mathrm{~T})$ & 43 & N/A & N/A \\
\hline Vegetatio & $120(\mathrm{~T})$ & $X(2)$ & N/A & $\mathrm{N} / \mathrm{A}$ \\
\hline \multicolumn{5}{|l|}{ Biological Reviews of the Cambridge } \\
\hline Philosophical Society & $400(\mathrm{~T})$ & $X(2)$ & N/A & N/A \\
\hline Agricultual and Forest Meteorology & 112 & N/A & 2 & 1.775 \\
\hline Journal of Vegetation Science & $186(\mathrm{~T})$ & $\mathrm{N} / \mathrm{A}$ & 3 & 1.73 \\
\hline Trees-Structure and Function & $44(\mathrm{~T})$ & $\mathrm{N} / \mathrm{A}$ & 4 & 1.42 \\
\hline Annals of Forest Science & 749 (T) & $\mathrm{N} / \mathrm{A}$ & 5 & 1.156 \\
\hline Agroforestry Systems & N/A & $\mathrm{N} / \mathrm{A}$ & 6 & 1.153 \\
\hline Plant Ecology & N/A & $\mathrm{N} / \mathrm{A}$ & 9 & 1.059 \\
\hline IAWA Journal & N/A & $\mathrm{N} / \mathrm{A}$ & 12 & 0.868 \\
\hline Natural Areas Journal 2 & $250(\mathrm{~T})$ & $\mathrm{N} / \mathrm{A}$ & 13 & 0.778 \\
\hline European Journal of Forest Pathology 4 & $400(\mathrm{~T})$ & $\mathrm{N} / \mathrm{A}$ & 14 & 0.744 \\
\hline Scandanavian Journal of Forest Patholog & ogy $\mathrm{N} / \mathrm{A}$ & $\mathrm{N} / \mathrm{A}$ & 15 & 0.692 \\
\hline Silva Fennica & 139 & $\mathrm{~N} / \mathrm{A}$ & 16 & 0.649 \\
\hline International Journal of Wildland Fire 5 & $576(\mathrm{~T})$ & $\mathrm{N} / \mathrm{A}$ & 17 & 0.571 \\
\hline New Forests & $65(\mathrm{~T})$ & $\mathrm{N} / \mathrm{A}$ & 19 & 0.519 \\
\hline Wood Science and Technology & $72(\mathrm{~T})$ & $\mathrm{N} / \mathrm{A}$ & 21 & 0.432 \\
\hline Forstwissenschaftliches Centralblatt & $179(\mathrm{~T})$ & $\mathrm{N} / \mathrm{A}$ & 23 & 0.411 \\
\hline Allgemeine Forst Und Jagdzeitung & $465(\mathrm{~T})$ & $\mathrm{N} / \mathrm{A}$ & 27 & 0.309 \\
\hline Forest Pathology & N/A & N/A & 28 & 0.176 \\
\hline \multicolumn{5}{|c|}{$\begin{array}{l}\text { Source: Peter McDonald, "Primary Journals and Serials in Forestry and Agroforestry," in The } \\
\text { Literature of Forestry and Agroforestry, ed. Peter McDonald and James Lassoie (Ithaca, N.Y. } \\
\text { Cornell Univ. Pr., 1996), 344-61. } \\
\text { 1. Rankings for the developed countries taken from the table "Top Journals Ranked by } \\
\text { Number of Citations to Them." See McDonald, pp. } 349-50 \text {. } \\
\text { 2. Titles appear in the table "Core Forestry and Agroforestry Journals for Developed and } \\
\text { Third World Countries." Titles do not appear in table noted above in footnote } 1 \text {. See } \\
\text { McDonald, pp. 357-61. } \\
\text { 3. JCR journals filtered by forestry category and then ranked by impact factor. } \\
\text { 4. T = tie. }\end{array}$} \\
\hline
\end{tabular}


ment on the LSU core list. The Soil Science Society of America Journal ranked eighth on the LSU core and sixteenth on the CALP list. Two of the soil journals, Soil Science Society of America Journal and Plant and Soil, ranked higher in the current study and a third journal, Soil Biology and Biochemistry, did not appear in the CALP list, providing further evidence of the importance of interdisciplinary journals to forest science research.

Both the CALP and LSU core lists contain a high number of ecological and environmental journals. Interestingly, five CALP journals with an environmental or ecological emphasis do not appear on the present core list for combined faculty (table 1). However, two of these five titles, Water, Air, and Soil Pollution and Ecological Monographs, appear on the assistant (both titles) and associate (Ecological Monographs) core lists. Neither appears on the professor core list. The remaining three titles, ranked at the lower end of the CALP core, were frequently cited in the present analysis; Journal of Ecology (ranked 38th) almost made the core and the other two titles, Journal of Applied Ecology and Annual Review of Ecology and Systematics, ranked among the top sixty-five titles. Ecology, Oecologia, and Environmental Pollution, shared by CALP and LSU lists, ranked higher on the LSU core. The appearance of Ecological Applications and the dramatic rise of Forest Ecology and Management on the LSU core list reflect the current emphasis on ecological research in forest science. Water Resources Research, Wetlands, and Journal of Environmental Quality appear only on the LSU core list of titles.

Interestingly, several of the plant science journals with a subject emphasis on botany or horticulture ranked high in the CALP core, but lower in the present study. For example, Canadian Journal of Botany ranked fifth in the CALP list and twenty-first in the current study. American Journal of Botany ranked thirteenth in the CALP core list and thirty-first in the current study. Journal of Experimental Botany ranked eighteenth in the CALP list and sixty-second in the current study. Annals of Botany, Botanical Gazette, and Australian Journal of Botany also ranked lower. Several of the horticultural journals, including Journal of the American Society for Horticultural Science and HortScience, ranked lower in the current study than in the CALP study. The decline does not reflect a decrease in JCR impact factors because these have remained relatively consistent for journals in both of these areas. Conversely, several of the plant science journals rose significantly on the LSU core list. In particular, two of the titles, Plant Cell and Environment and Plant and Soil, rose significantly as listed in table 9. The rise of these two plant science titles may perhaps be attributed to the greater interdisciplinarity of both journals. Most of the botanical and horticultural journals are less interdisciplinary in nature, and faculty appear to be citing these journals less frequently. Notwithstanding this apparent trend, two of the journals, Canadian Journal of Botany and Journal of the American Society for Horticultural Science, retain their status as significant core titles for forestry on both the LSU and CALP lists. Plant science journals constitute a prominent presence on both lists.

The current study corroborates and builds on the Cornell study. Six journals appeared in the top ten journals for both studies. Canadian Journal of Forest Research and Forest Science appeared as the top two journals in both studies. The Cornell study identified some up-and-coming journals for the field of forestry, including Tree Physiology, Holzforschung, and Wood and Fiber Science. Tree Physiology, which did not garner sufficient citations to make the CALP core list of sixty journals, ranked sixth in the current study. Similarly, Holzforschung and Wood and Fiber Science, which appeared on CALP's core list of sixty journals, but not on the CALP ranked core, ranked eighteenth and twenty-fourth, respectively, in the current study. Two additional titles identified by CALP as up-and-coming journals, Trees-Structure and Function and New Forests, ranked forty-fourth and sixty-fifth, respectively, in the LSU study. These titles did not appear in the top 50 percent of cumula- 


\begin{tabular}{|c|c|c|c|c|c|c|}
\hline \multicolumn{7}{|c|}{$\begin{array}{c}\text { TABLE } 10 \\
\text { Journals Cited Categorized by AGRICOLA Subject Category Codes } \\
\end{array}$} \\
\hline & Subject Description & $\begin{array}{l}\text { No. of } \\
\text { Journals }\end{array}$ & $\begin{array}{c}\text { No. of } \\
\text { Citations }\end{array}$ & $\begin{array}{c}\% \text { of } \\
\text { Citations } \\
\end{array}$ & $\begin{array}{c}\text { Overall \% } \\
\text { of Journals }\end{array}$ & $\begin{array}{r}\text { Overall \% } \\
\text { of Citations }\end{array}$ \\
\hline \multicolumn{3}{|c|}{ Forestry Code(s) Only: } & & & 4.1 & 22.36 \\
\hline K000-K130 & Forestry Production & 30 & 2,551 & 71.86 & & \\
\hline K200 & Forest Management & 7 & 35 & 0.99 & & \\
\hline K500-K530 & Forest Products & 14 & 964 & 27.15 & & \\
\hline Total & & 52 & 3,550 & 100 & & \\
\hline \multicolumn{3}{|c|}{ Forestry and Secondary Codes: } & & & 1.1 & 7.35 \\
\hline K000-K001 & Forestry & 9 & 686 & 58.78 & & \\
\hline K200 & Forest Management & 1 & 431 & 36.93 & & \\
\hline K500-K530 & Forest Products & 3 & 48 & 4.11 & & \\
\hline K810 & Forest Fire Managemen & ent 1 & 2 & 0.18 & & \\
\hline Total & & 14 & 1,167 & 100 & & \\
\hline \multicolumn{2}{|c|}{ Non-Forestry Code(s) Only: } & & & & 40.19 & 53.85 \\
\hline A000 & Agriculture & 15 & 65 & 0.76 & & \\
\hline B100-B200 & $\begin{array}{l}\text { Geography, Meteorolog } \\
\text { \& Climatology }\end{array}$ & ogy & 86 & 1.01 & & \\
\hline $\mathrm{C} 100$ & Agricultural Education & 1 & 1 & 0.01 & & \\
\hline E100-E550 & Agricultural Economics & cs 16 & 88 & 1.02 & & \\
\hline F000-F900 & Plant Science & 105 & 2,418 & 28.27 & & \\
\hline H000 & Pesticides & 1 & 2 & 0.02 & & \\
\hline J000-J700 & Soil Sciences & 18 & 493 & 5.76 & & \\
\hline L000-L832 & Animal Science & 25 & 82 & 0.96 & & \\
\hline M120-M300 & $\begin{array}{l}\text { Aquaculture; Aquatic } \\
\text { Biology and Ecology }\end{array}$ & 5 & 99 & 1.16 & & \\
\hline N000 & $\begin{array}{l}\text { Agricultural Engineerin } \\
\text { and Safety }\end{array}$ & ing & 16 & 0.19 & & \\
\hline P000-P300 & Natural Resources & 38 & 883 & 10.33 & & \\
\hline Q000-Q500 & Food Science & 5 & 35 & 0.41 & & \\
\hline S000-S200 & Agricultural Products & 2 & 3 & 0.04 & & \\
\hline T000 & Human Nutrition & 2 & 2 & 0.02 & & \\
\hline U000 & Home Economics & 3 & 4 & 0.05 & & \\
\hline W000 & Pollution & 20 & 342 & 4 & & \\
\hline \multirow{2}{*}{$\begin{array}{l}\text { X000-X200, } \\
\text { X400-X800 } \\
\text { X300 }\end{array}$} & Auxiliary Disciplines & 106 & 799 & 9.34 & & \\
\hline & $\begin{array}{l}\text { Life Sciences (Auxiliary } \\
\text { Disciplines) }\end{array}$ & $r y$ & 3,134 & 36.65 & & \\
\hline \multicolumn{2}{|c|}{ Total } & 510 & 8,552 & 100 & & \\
\hline \multirow{2}{*}{\multicolumn{2}{|c|}{$\begin{array}{l}\text { No Codes Assigned: } \\
\text { Totals }\end{array}$}} & 693 & 2,611 & & 54.61 & 16.44 \\
\hline & & 1,269 & 15,880 & & & \\
\hline
\end{tabular}

tive citations, but their placement on the LSU list shows that they received a fairly large number of citations. In fact, TreesStructure and Function ranked twenty-first in the assistant professors' core list, indicating its prominence for researchers new to the field.
The investigators designed the methodology of the study to minimize bias and outliers. In most cases, a large number of citations from a noncore journal by a single professor would not have been sufficient to make the core list. However, one of the core titles, Journal of Chemical 
Information and Computer Sciences, received over 90 percent of the citations from a highly prolific team of researchers. One professor and one associate professor cited the journal numerous times, and hence the title appears on both of the core lists for these individual ranks. The journal is not cited by any other faculty member in the study and should be considered an outlier to the core. Ecological Monographs ranked thirty-sixth and would replace Journal of Chemical Information and Computer Sciences on the present core list. Ecological Monographs also ranked thirty-fifth on CALP's ranked core list.

Table 10 reveals that forestry researchers predominantly cite journals assigned nonforestry subject AGRICOLA SCC. Not surprisingly, the journals assigned a primary Life Sciences SCC (a subdivision of Auxiliary Disciplines) received the largest percentage of citations $(36.65 \%)$ for nonforestry journals. Of the 139 journals assigned the life sciences code, nine appear in the core list of journals cited (table 1). These titles include Ecology, Oecologia, Science, and Theoretical and Applied Genetics ranked fifth, tenth, thirteenth, and twenty-third, respectively. The Plant Science SCC journals garnered the second highest percentage $(28.27 \%)$ of citations for nonforestry journals. Ten of the journals assigned a primary Plant Science SCC appear in the core title list (table 1). These titles include Plant Physiology, Plant Cell and Environment, Physiologia Plantarum, and Plant and Soil, which ranked twelfth, sixteenth, seventeenth, and nineteenth, respectively. Faculty cited a much smaller number of articles from journals assigned forestry codes, just 29.71 percent of the overall citations. The data in table 10 indicate that forestry faculty heavily rely on interdisciplinary journals for their research.

A large number of journals from several disciplines constitute the present core list. The core list contains only ten journals specific to forestry. However, these ten journals ranked highly on the core and account for 24.9 percent of total citations, illustrating their importance to forest science research. Of the twenty-five remaining journals, 25.3 percent (over half the citations needed to meet $50 \%$ ) constitute a significant portion of the core. The core list contains ten plant science journals, or 9.9 percent of total citations. Seven journals, 7.8 percent of total citations, are devoted to ecological and environmental research. Ecological journals include Ecology, Oecologia, Ecological Applications; and it should be noted that several of the plant science journals include an ecological component. Environmental journals include Journal of Environmental Quality, Plant Cell and Environment, Environmental Pollution, Water Resources Research, and Wetlands. Genetics and soil science journals also are strongly represented on the core list.

Differences exist in citation patterns among the three faculty ranks for the plant science journals. The shift in research emphasis is strikingly evident among both the assistant and associate professors. The top half of the core journals for assistant professors (table 4) consists of five plant science journals, including New Phytologist and Plant Physiology, which rank ninth and eleventh, respectively. The top half of the core journals for associate professors (table 3) consists of four plant science journals, with the two preceding titles ranking fifth and eleventh, respectively. In comparison, plant science journals do not appear at all in the top half of the core journals for professors (table 2), with Plant Physiology appearing sixteenth and New Phytologist not appearing at all. For assistant professors, the concentration of plant science journals is weighted at the top portion of the core journal list, whereas the concentration for the professors is weighted toward the bottom of their core list. The journals are dispersed fairly equally among the core list for associate professors. The percentage of total citations for plant science journals varied among the three faculty ranks: 6.2 percent for professors, 11.2 percent for associate professors, and 10.5 percent for assistant professors. (See table 11.) 


\begin{tabular}{|c|c|c|c|}
\hline \multicolumn{4}{|c|}{$\begin{array}{l}\text { TABLE } 11 \\
\text { Combined List of Core Plant Science Journals } \\
\text { Cited for Each Faculty Rank (1990-2002) }\end{array}$} \\
\hline & $\begin{array}{l}\text { Professors } \\
\text { Core Rank } \\
\text { Table } 2 \\
\end{array}$ & $\begin{array}{l}\text { Associates } \\
\text { Core Rank } \\
\text { Table } 3 \\
\end{array}$ & $\begin{array}{c}\text { Assistants } \\
\text { Core Rank } \\
\text { Table } 4 \\
\end{array}$ \\
\hline American Journal of Botany & 21 & $\mathrm{~N} / \mathrm{A}$ & N/A \\
\hline $\begin{array}{l}\text { Canadian Journal of Botany } \\
\text { Journal of the American Society }\end{array}$ & N/A & 15 & N/A \\
\hline for Horticultural Science & $\mathrm{N} / \mathrm{A}$ & 26 & N/A \\
\hline Molecular Plant-Microbe Interactions & $\mathrm{N} / \mathrm{A}$ & 25 & $\mathrm{~N} / \mathrm{A}$ \\
\hline New Phytologist & N/A & 5 & 9 \\
\hline Physiologia Plantarum & 22 & 21 & 10 \\
\hline Phytochemistry & 15 & N/A & N/A \\
\hline Phytopathology & $\mathrm{N} / \mathrm{A}$ & 14 & $\mathrm{~N} / \mathrm{A}$ \\
\hline Plant and Soil & N/A & 29 & 8 \\
\hline Plant Cell and Environment & 25 & 17 & 7 \\
\hline Plant Cell Reports & 26 & N/A & N/A \\
\hline Plant Physiology & 16 & 11 & 11 \\
\hline Plant Science Citations & 425 & 619 & 362 \\
\hline Total Citations & 6,870 & 5,547 & 3,463 \\
\hline Percent of Total Citations & 6.2 & 11.2 & 10.5 \\
\hline
\end{tabular}

The percentage of total citations for the ecological and environmental journals varied significantly among the three faculty ranks: 6.5 percent for professors, 8.9 percent for associate professors, and 14.7 percent for assistant professors. Only five ecological and environmental journals appear on the professor core list. The associate core list includes seven titles, and the assistant professor core includes eight ecological and environmental journals. The evidence reveals that assistant professors and associate professors conduct more research using ecological and environmental journals than full professors do. Indeed, assistant professors appear to cite over twice as many ecological and environmental journals as professors. Clearly, the assistant and associate professors cited significantly more ecological and environmental journals than professors. (See table 12.)

Citation patterns in the present study reflect the "modern 'ecosystem' approach" to forest science outlined by the Society of American Foresters. The field of forestry is becoming more interdisciplinary and holistic in scope. Changes to the curriculum at forestry schools emphasize the integration of ecological forestry practices and research. Assistant professors, with newly minted Ph.D.'s in forest science, reflect these changes in their research interests and cited the largest percentage of core journals emphasizing ecological and environmental research. Both assistant and associate professors cited a large number of journals devoted to plant science, and faculty from all three ranks frequently cited interdisciplinary journals in their publications. The core lists illustrate the importance of ecological and interdisciplinary research to forest science.

\section{Conclusion}

The present study produced a current core list of forestry titles with important differences from, and similarities to, the Cornell study. Several titles appear only in the LSU core list. The study produced separate core lists for assistant, associate, and full professor faculty ranks, and re- 
TABLE 12 Combined List of Core Ecological and Environmental Journals
Cited for Each Faculty Rank (1990-2002)

\begin{tabular}{lccc}
\hline \hline & $\begin{array}{c}\text { Professors } \\
\text { Core Rank } \\
\text { Table 2 }\end{array}$ & $\begin{array}{c}\text { Associates } \\
\text { Core Rank } \\
\text { Table 3 }\end{array}$ & $\begin{array}{c}\text { Assistants } \\
\text { Core Rank } \\
\text { Table 4 }\end{array}$ \\
\hline American Midland Naturalist & 28 & N/A & N/A \\
Applied and Environmental Microbiology & N/A & 31 & N/A \\
Ecological Applications & N/A & N/A & 15 \\
Ecological Monographs & N/A & N/A & 22 \\
Ecology & 6 & 19 & 5 \\
Environmental Pollution & N/A & 7 & N/A \\
Functional Ecology & N/A & N/A & 17 \\
Global Change Biology & N/A & N/A & 18 \\
Journal of Environmental Quality & 20 & 10 & 25 \\
Oecologia & 24 & 22 & 2 \\
Water, Air, and Soil Pollution & N/A & 24 & 14 \\
Water Resources Research & N/A & 12 & N/A \\
Wetlands & 18 & N/A & N/A \\
\hline Ecological and Environmental Citations & 449 & 493 & 508 \\
Total Citations & 6,870 & 5,547 & 3,463 \\
Percent of Total Citations & 6.5 & 8.9 & 14.7 \\
\hline
\end{tabular}

vealed significant differences in citation patterns among the three groups. Assistant professors and associate professors used more journals with ecological, environmental, and plant science subject emphases than full professors did. The study also yielded important data on the AGRICOLA SCC designations for the universe of journals.

The current study provides information useful to collection development librarians in analyzing holdings relevant to forestry. It may be particularly useful to determine titles of interdisciplinary importance for a library collection. In addition, the core list may be useful to forestry faculty in making promotion and tenure decisions, and may serve as a guide for faculty to identify journal titles for potential publications. Indexers for agriculture databases, for ex- ample, AGRICOLA indexers, may wish to consult the core when deciding which forestry titles to cover.

Further studies of a national and regional nature are recommended to corroborate the findings of the present analysis and analyze any differences in citation patterns among other groups of forest science researchers. Studies are needed in the future to track and analyze citation differences among the three faculty ranks. More citation studies are needed to analyze differences, if any, that exist between monographs and journal literature. Cornell University published its study in 1994, relying largely on data from the mid-1980s. The present study analyzed publications from 1990-2002; updated studies for core lists in forestry are needed on a more regular basis.

\section{Notes}

1. John A. Helms, "Forest, Forestry, Forester: What Do These Terms Mean," Journal of Forestry 100, no. 8 (2002): 18.

2. Ibid., 16.

3. Thomas W. Steele and Jeffrey C. Stier, "The Impact of Interdisciplinary Research in the Environmental Sciences: A Forestry Case Study," Journal of the American Society for Information 
Science 51 (2000): 476.

4. V. Alaric Sample, et al., "Forestry Education: Adapting to the Changing Demands on Professionals," Journal of Forestry 97, no. 9 (Sept. 1999): 4.

5. Bob Blackmon, Louisiana State University, School of Renewable Natural Resources, "Director's Message." Available online from http://www.fwf.lsu.edu/directors_message.htm.

6. Mary M. Case, "The Impact of Serial Costs on Library Collections." Available online from http:/ / www.arl.org/newsltr/218/ costimpact.html.

7. Paul D. Burnam, "Private Liberal Arts Colleges and the Costs of Scientific Journals: A Perennial Dilemma," College E Research Libraries 59 (Sept. 1998): 406-20.

8. Case, "The Impact of Serial Costs on Library Collections."

9. Ulrich's International Periodicals Directory, 35th ed. New York: Bowker, 1997; Ulrich's Periodicals Directory, 39th ed. New Providence, N.J.: R.R. Bowker, 2001. 86.

10. S. C. Bradford, "Sources of Information on Specific Subjects," Engineering 137 (Jan. 1934):

11. Kathleen E. Joswick and Jeanne Koekkoek Stierman, "The Core List Mirage: Comparison of the Journals Frequently Consulted by Faculty and Students," College \& Research Libraries 58 (Jan. 1997): 48.

12. Lois Kuyper-Rushing, "Identifying Uniform Core Journal Titles for Music Libraries: A Dissertation Citation Study," College \& Research Libraries 60 (Mar. 1999): 153-63.

13. Thomson/ISI, "Subject Categories," ISI Journal Citation Reports, Science Edition, 2001 [CDROM] (Philadelphia: Institute for Scientific Information, 2002).

14. Thomas E. Nisonger, "Use of the Journal Citation Reports for Serials Management in Research Libraries: An Investigation of the Effect of Self-citation on Journal Rankings in Library and Information Science and Genetics," College \& Research Libraries 61 (May 2000): 263-75.

15. Thomson/ISI, "What Is the JCR?," ISI Journal Citation Reports, Science Edition, 2001 [CDROM] (Philadelphia: Institute for Scientific Information, 2002).

16. Nisonger, "Use of the Journal Citation Reports for Serials Management in Research Libraries," 263-75.

17. Claudia Lascar and Loren D. Mendelsohn, "An Analysis of Journal Use by Structural Biologists with Applications for Journal Collection Development Decisions," College \& Research Libraries 62 (Sept. 2001): 422-33.

18. Angela M. Gooden, "Citation Analysis of Chemistry Doctoral Dissertations: An Ohio State University Case Study," Issues in Science and Technology Librarianship no. 32 (fall 2001). Available online from http://www.istl.org/istl/01-fall/refereed.html.

19. Louise S. Zipp, "Core Serial Titles in an Interdisciplinary Field: The Case of Environmental Geology," Library Resources \& Technical Services 43 (Jan. 1999): 28-36.

20. Ibid., 30.

21. Luti Salisbury, "Entomology Faculty Publications as a Source of Information for Collection Development: A Case Study at the University of Arkansas." Paper presented at the annual meeting of the United States Agricultural Information Network, Champaign, Ill., Apr. 2003.

22. Y.M. Patil, "Agropedology Literature: Evaluation and Citation Analysis," Agropedology 6 (1996):107-12.

23. Segun Adewole, "Selecting Livestock Periodicals through Citation Analysis Technique," Information Processing \& Management 23 (1987): 629-38.

24. Steele and Stier, "The Impact of Interdisciplinary Research in the Environmental Sciences," $476-84$.

25. Stephanie C. Haas and Kate Lee, "Research Journal Usage by the Forestry Faculty at the University of Florida, Gainesville," Collection Building 11, no. 2 (1991): 23-25.

26. Pamela J. Jakes and Andra Slimak VanDyne, "Forestry Literature: Who's Publishing What Where?" Journal of Forestry 85, no. 9 (Sept. 1987): 33-36.

27. Peter McDonald and James Lassoie, eds., The Literature of Forestry and Agroforestry (Ithaca, N.Y.: Cornell Univ. Pr., 1996), ix.

28. Peterson's Graduate Programs in the Physical Sciences, Mathematics, Agricultural Sciences, the Environment \& Natural Sciences, 35th ed. (Princeton, N.J.: Peterson's, 2001). 